\title{
Epidemiology of Malaria Used Surveillance Data in Buton Utara District, Indonesia
}

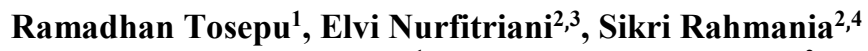 \\ \{ramadhan.tosepu@uho.ac.id ${ }^{1}$,elvi_nurfitriani@yahoo.co.id ${ }^{2}$ \} \\ ${ }^{1}$ Faculty of Public Health, Halu Oleo University, Kendari, Indonesia \\ ${ }^{2}$ The Postgraduate program, Halu Oleo University, Indonesia \\ ${ }^{3}$ Dinas Kesehatan Kabupaten Buton Utara, Sulawesi Tenggara, Indonesia \\ ${ }^{4}$ Dinas Kesehatan, Kabupaten Muna Barat, Sulawesi Tenggara, Indonesia
}

\begin{abstract}
Malaria is one of the public health problems that can cause death especially in high-risk groups, namely infants, toddlers, pregnant women, besides Malaria directly causes anemia and can reduce work productivity. This disease is also still endemic in most parts of Indonesia. This study was used from various data from the governments of Indonesia. Data from Malaria cases were obtained from the Health Office of Buton Utara district from 2015 to 2018 . The conclusion is that the majority of malaria sufferers in Buton Utara district are male with some distributions that tend to decline from year to year. The incidence of Malaria in Buton Utara district tends to increase in April, May and October and peak in May. The majority of malaria sufferers in Buton Utara district are in the age range of 17-25 years.
\end{abstract}

Keywords: Malaria, Southeast Sulawesi, Indonesia.

\section{Introduction}

Malaria is a disease caused by Plasmodium carried by Anopheles. Plasmodium vivax causes tertiary vivax / malaria and is found in subtropical and tropical regions [1]. Malaria in this type of Plasmodium has a hypnozoite phase so that this type of malaria can re-infect (relapse) but vice versa with Plasmodium falciparum [2],[3],[4].Plasmodium falciparum is found in tropical regions, especially Africa and Southeast Asia [5].

Malaria is an infectious and contagious disease that still requires great attention, especially in Buton Utara District. Almost all of the regions are endemic malaria areas, of which there are only six sub-districts which are free of malaria. To change the endemicity map, the local government through the District Health Service seeks all means, so that Buton Utara can be free from malaria. This has been proven for five years in a thousand population of malaria morbidity or the Annual Paracency Incidence (API) in Buton Utara District which has decreased significantly. In 2009 malaria morbidity reached $9.07 \%$, in 2010 it increased to $15.54 \%$ o then reduced to $5.74 \%$ in $2011,0.77 \%$ in 2012 and $0.13 \%$ in the year Th 2013 of $0,22 \%$, in 2006 amounting to $0.37 \%$; in 2007 amounted to $0.23 \%$ and in 2014 amounted to $0.21 \%$.

However, environmental conditions, related to the presence of malaria-transmitting vectors in Buton Utara, cause almost all regions in Buton Utara district to allow malaria transmission to occur. The occurrence of a disease involves three aspects, namely the host, agent, and environment. Host in this case human, to be sick depends on many things, namely behavior, endurance, immunity. The agent for malaria is Plasmodium, while the environment 
is the environment, the situation that supports malaria transmission is an environment suitable for mosquitoes transmitting the disease to breed and allow contact between mosquitoes and humans.

In April malaria cases were found in Bonegunu Subdistrict, Buton Utara district on PCD with the laboratory results of Plasmodium vivax trophozoites ring gametocytes. The gametocyte phase is the transmission phase for malaria. With the discovery of cases in the gamete phase, there is a high probability of transmission. The previous year in the same month malaria cases was zero. This activity aims to find other malaria sufferers and find out the type of Plasmodium that causes malaria, know the distribution of malaria cases, find out the mosquitoes suspected of malaria vectors and breeding sites or habitat, predict the place of malaria transmission and find out if there is local transmission of malaria in Bonegunu Subdistrict, Buton Utara district so that it can provide recommendations for malaria prevention in the hope that the existing cases can be detected and the spread of the area of Extraordinary Events can be limited

\section{Methods}

Buton Utara district with the capital in Buranga is one of the districts in Southeast Sulawesi Province whose territory covers parts of northern Buton Island, as well as small islands scattered around the area. Buton Utara district is located in the South of the Equator at latitude 4006 'up to 50 15' South Latitude, and from West to East 122059 'East Longitude to 1230 15' East Longitude.

This study used various data from the governments of Indonesia. Data of Malaria cases were obtained from the Health Office Buton Utara from 2015 to 2018. Data were extracted from an annual health fact sheet published by district health offices Buton Utara. The research findings were presented in figure format.

\section{Results}




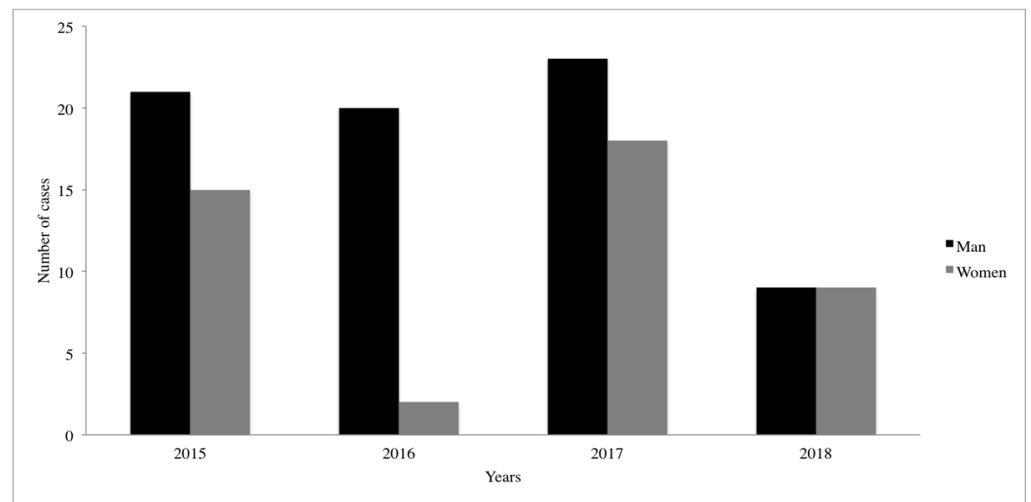

Figure 1. Number of cases by gender in Buton Utara district

The results showed that based on gender, from 2015 to 2017 the distribution of patients with malaria was more prevalent in men, in 2018 the distribution of malaria patients between men and women was the same, but the frequency of sufferers was relatively small compared to previous years. This means that efforts to deal with malaria in Buton Utara have produced better results in 2018 (Figure 1).

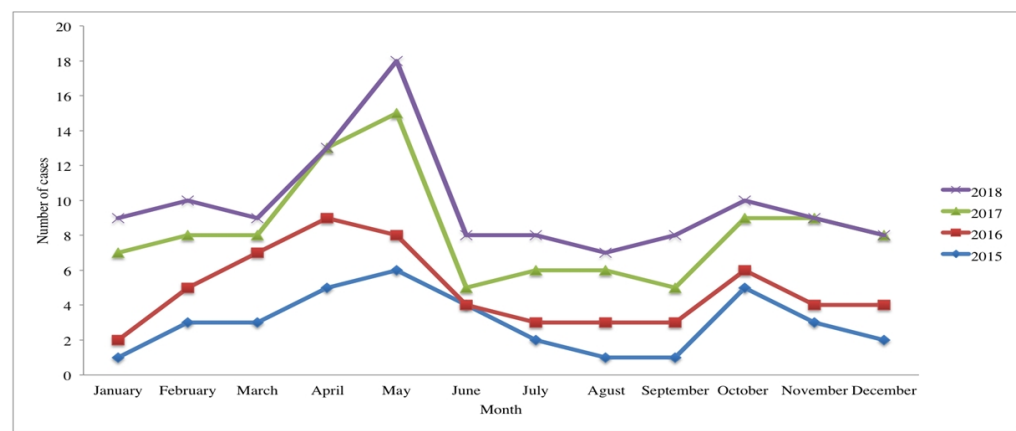

Figure 2. Number of cases by years in Buton Utara district

Based on the distribution of malaria incidence from year to year, the results showed that the distribution of malaria sufferers always fluctuated every month. From January it tends to increase in the following months, and its occurrence occurs in April and May, then decreases in the next month, and tends to be stable from July to September and again increases in October (Figure 2). 


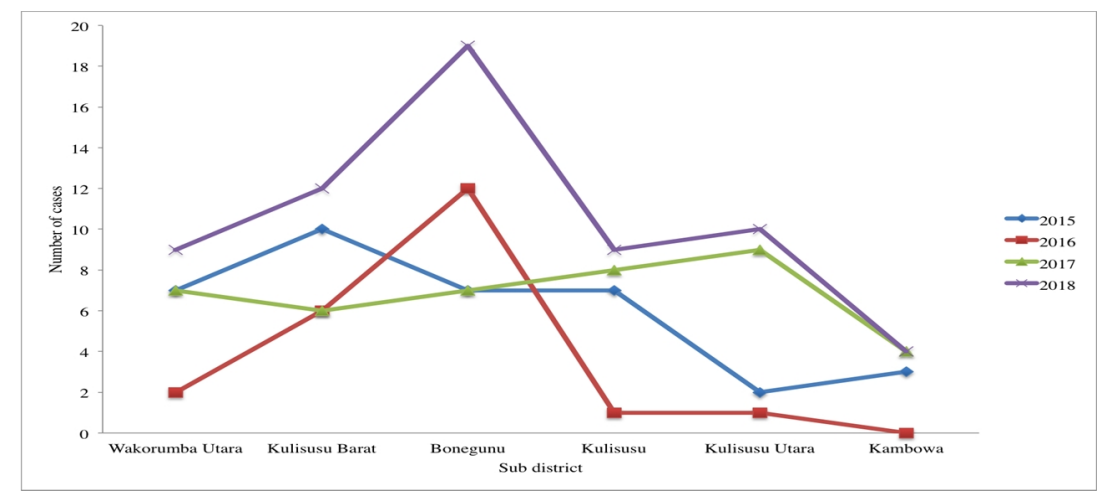

Figure 3. Number of cases by Sub-district in Buton Utara district

Based on sub-districts in North Buton it is known that in 2016 and 2018 the incidence of malaria was most prevalent in the Bonegunu sub-district, in 2015 it was most prevalent in the Kulisusu Barat sub-district, whereas in 2017 it was most prevalent in the northern Kulisusu (Figure 3).

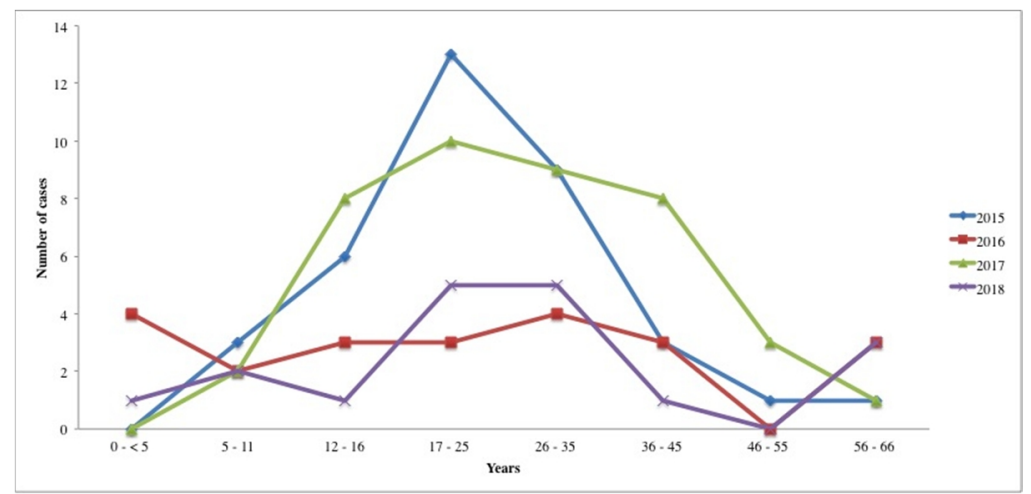

Figure 4. Cases of malaria by years in Buton Utara district

Based on age, the distribution of malaria sufferers showed fluctuating results, wherein 2015 the majority of patients aged 17-25 years with the highest number compared to the following years, in 2016 the incidence of malaria decreased quite significantly with relatively even distribution in all ages, not even found cases at the age of 45-55 years. In 2018 the incidence of malaria again increased with the number of sufferers left at the age level of 17-25 years, but no cases were found at the age of $<5$ years. In 2018 the incidence of malaria returned according to quite significant with the highest number of patients occurring at the age of 17-25 years and generations 26-35 years, but no cases were found at the period of 46-55 years (Figure 4).

\section{Discussion}

The proportion of malaria cases in men is $51 \%$ while for women it is $49 \%$ [6]. Two thousand thirteen important health research reports that it is known that the proportion of 
positive malaria cases by sex tends to be the same. This is because the percentage of malaria cases in men is $1.6 \%$ while in women it is $1.1 \%$ [7].

Population mobility in Buton Utara district contributes to the occurrence of Malaria, besides that community behavior that allows transmission, the widespread of malaria parasites that have been resistant to anti-malaria drugs, limited access to health services to reach all villages with malaria problems due to geographical barriers, economy, and resources

Based on the Age Group, the highest incidence of malaria in Buton in the age group 1725. The age group is an adult. Malaria sufferers in adults are more significant than children [8]. Malaria sufferers were found to be dominated by adult age groups. This is thought to be caused by the activities of more adults outside the home than children so that the possibility of developing malaria through the bite of the more massive Anopheles mosquito. The reason why malaria affects the productive age group (17-25) and more men may be because in Buton Utara District the work of the population is agriculture so that the male population cultivates agricultural land. This condition can cause them to get mosquito bites.

\section{Conclusion}

The majority of malaria sufferers in Buton Utara are male with some distributions that tend to decline from year to year. The incidence of malaria in Buton Utara tends to increase in April, May, and October and experiences a peak in May. The majority of malaria sufferers in Buton Utara are in the age range of 17-25 years.

\section{Reference}

[1] J. C. P. Rodríguez, G. Á. Uribe, R. M. Araújo, P. C. Narváez, and S. H. Valencia, "Epidemiology and control of malaria in Colombia," Memórias do Instituto Oswaldo Cruz, vol. 106, pp. 114-122, 2011.

[2] Y. Wang, Y. Li, J. Liu, Y. Zhao, Z. Xie, J. Shen, et al., "Genetic characterization of human bocavirus among children with severe acute respiratory infection in China," Journal of Infection, vol. 73, pp. 155-163, 2016/08/01/ 2016.

[3] F. Mau, "Hubungan Antara Curah Hujan dan Temperatur dengan Malaria di Kabupaten Sumba Barat Daya Provinsi Nusa Tenggara Timur-Indonesia," Buletin Penelitian Kesehatan, vol. 46, pp. 129-134, 2018.

[4] D. Alonso, M. J. Bouma, and M. Pascual, "Epidemic malaria and warmer temperatures in recent decades in an East African highland," Proceedings of the Royal Society B: Biological Sciences, vol. 278, pp. 1661-1669, 2010.

[5] S. Konchom, P. Singhasivanon, J. Kaewkungwal, S. Chupraphawan, K. Thimasarn, C. Kidson, et al., "Trend of malaria incidence in highly endemic provinces along the Thai borders, 1991-2001," Southeast Asian journal of tropical medicine and public health, vol. 34, pp. 486-494, 2003.

[6] T. B. Purnama, "Epidemiologi Kasus Malaria di Kota Lubuk Linggau, Sumatera Selatan," Jurnal Ilmu Kesehatan Masyarakat, vol. 6, pp. 164-170, 2017.

[7] K. Kesehatan and K. K. RI, "Riset kesehatan dasar," Jakarta: Badan Penelitian dan Pengembangan Kesehatan Departemen Kesehatan Republik Indonesia, 2013.

[8] B. G. Williams, E. Gouws, C. Boschi-Pinto, J. Bryce, and C. Dye, "Estimates of worldwide distribution of child deaths from acute respiratory infections," The Lancet infectious diseases, vol. 2, pp. 25-32, 2002. 